УДК 811.161’2.36

\title{
В. В. Рингевич
}

\section{ЛИТЕРАТУРНЫЙ ДИСКУРС И КИНОДИСКУРС В СИСТЕМЕ АРТ-ДИСКУРСА}

Рингевич В. В. Літературний дискурс і кінодискурс у системі арт-дискурсу.

У статті розглянуто арт-дискурс, що $є$ основним із різновидів дискурсу, співвідносних із мистецтвом, до сфери якого входять літературний дискурс, музичний дискурс, дискурс образотворчого мистецтва, модельний дискурс тощо. Оскільки артдискурс відображає сучасні явища за допомогою мовних засобів і становить як зв'язний текст, що інтерпретує об'єкт мистецтва разом 3 екстралінгвальними факторами, так і комунікативну діяльність, де мають бути відправник й отримувач інформації, то до різновидів арт-дискурсу уналежнено не тільки літературний дискурс, але й кінодискурс.

Ключові слова: літературний дискурс, кінодискурс, арт-дискурс, дискурс-аналіз. 
Рингевич В. В. Литературный дискурс и кинодискурс в системе арт-дискурса.

В статье рассматривается арт-дискурс, который является основным из видов дискурса, имеющих отношение к искусству, в сферу которого входят литературный дискурс, музыкальный дискурс, дискурс изобразительного искусства, модельный дискурс и др. Так как арт-дискурс отражает современные явления с помощью языковых средств и представляет из себя как связный текст, интерпретирующий объект искусства в совокупности с экстралингвистическими факторами, так и коммуникативную деятельность, где должен присутствовать отправитель и получатель информации, в качестве вида арт-дискурса рассматривается не только литературный дискурс, но и кинодискурс.

Ключевые слова: литературный дискурс, кинодискурс, арт-дискурс, дискурс-анализ.

Rynhevich V. V. Literary discourse and film discourse in terms of art discourse.

Most often the discourse-analysis theories focus on the following discourse-objects: discourses of everyday communication, institutional discourses, public discours, political discourse, media discourses, art discourses etc. So the article is about the art discourse which is one of the main kinds of discourse. The art discourse has not received wide extention in modern linguistics yet and seems to be understudied. There are the literary discourse, the music discourse, the visual art discourse, the model discourse, etc. in the sphere of art. The art discourse reflects modern phenomena with the help of language means. It represents both a textual unity, which interprets an art object together with extra textual factors, and the communication activity where should present a sender and a recipient of information. Due to the above-mentioned, not just the literary discourse but also the film discourse are passed in review in this article. In that article we consider literary discourse as a communicative process of information delivery from an author to a reader. As a result, a kind of a message appears. The article also deals with features and functions of the literary discourse and the film discourse. Main features of the literary discourse are a written form, wholeness and completeness, polymorthy, blured distinction between the truth and a lie towards an objective reality. Functions of the literary discourse are the following: informative, creative. The film discourse is considered both in narrow and broad senses in the article. In a narrow sense, the film discourse is "an oral, written, visual message, expressed with verbal/ visual signs". In broader sense, the film discourse is a process of creating, playing out and percepting the film. This process includes the synthesis of the participants of the discourse, i.e. their speech, time and space of their co-operation. Action, formation of characters and their relationship, and also the development of their natures happen with the help of this synthesis. Main features of the film discourse are wholeness and completeness, usage of the film language tools, the synthesis of a personality's speech activity and a non-verbal component, presence of broad extratextual factors. Main functions of the film discourse are informative and the function of influence. Therefore, according to criteria of genre and functional style, the literary discourse and the film discourse refer to the art discourse. The most important object of studying both kinds of art discourse is works of art, i.e. fiction and feature films accordingly.

Key words: literary discourse, film discourse, art discourse, discourse analysis.

\section{В своей работе «Основы теории дискурса» М. Макаров} представил классификацию теорий дискурса, которая базируется на том, какие дискурс-объекты отражаются в той или иной классификации.

() В. В. Рингевич, 2017. 
Интерес для нашего исследования представляют дискурс кино и литературный дискурс. Близкие друг другу объекты, являющие собой произведения искусства, оказались расположены М. Макаровым в абсолютно разных классификациях: медиадискурс и арт-дискурс. И если медиадискурс является достаточно изученным (Т. Добросклонская, Е. Кожемякин, М. Коновалова, Е. Уварова, Л. Филлипс и др.), то артдискурс пока не получил широкого распространения в современной лингвистике и представляется новым мало изученным понятием.

Целью исследования является установление таксономических характеристик таких разновидностей арт-дискурса, как литературный дискурс и кинодискурс.

Наиболее часто в фокусе теорий дискурс-анализа оказываются следующие дискурс-объекты:

1) дискурсы повседневного общения (бытовые разговоры, дружеские беседы, слухи, бытовые конфликты и др.);

2) институциональные дискурсы (административный, офисный, банковский, педагогический, медицинский, армейский, церковный и др.);

3) публичный дискурс (дискурсы гражданских инициатив и выступлений, дипломатический дискурс, PR-дискурс и др.);

4) политический дискурс (политических идеологий, политических институтов, политических акций и др.);

5) медиадискурсы (ТВ-дискурс, дискурс кино, рекламы и др.);

6) арт-дискурсы (литературный, музыкальный, модельный, дискурс изобразительного искусства и др.);

7) дискурс деловых коммуникаций (деловых переговоров, бизнес-коммуникаций);

8) маркетинговые дискурсы (рекламы, продаж, потребительский, сервисный и др.);

9) академические дискурсы (научных сообществ, научных и гуманитарных дисциплин);

10) культурно-мировоззренческие дискурсы (культурных эпох, различных философских и религиозных течений) [5, с. 27].

Классификация дискурсов осуществляется по следующим независящим друг от друга критериям, представленным в исследованиях С. Слембрука:

1) критерий модуса (письменный или устный); 
2) критерий жанра (наличие определенной жанровой схемы, присущей для дискурса данного жанра);

3) критерий функционального стиля (определяется исходя из сферы человеческой жизни: бытовая, научная, официальная, публицистическая, художественная) [10].

Если рассматривать кинодискурс и литературный дискурс по трем, приведенным выше критериям, то по двум последним мы можем рассматривать оба дискурса в качестве объектов одной классификации, ведь, изучая литературный дискурс, мы имеем дело с некоторым художественным произведением, представляющим собой продукт художественного творчества, в котором в чувственноматериальной форме воплощен замысел его создателя-художника и который отвечает определенным категориям эстетической ценности. Изучая кинодискурс, мы изучаем художественный фильм, который представляет собой произведение киноискусства, имеющее в основе сюжет, воплощенный в сценарии и интерпретируемый режиссером, который создается с помощью актерской игры, режиссерского, операторского и прочих искусств.

Исходя из приведенных выше определений, мы считаем возможным рассматривать кинодискурс и литературный дискурс в качестве продуктов арт-дискурса, так как оба дискурса базируются на произведениях искусства.

Термин «арт-дискурс» не имеет четкого определения, однако в словаре терминов М. Адрианова представляется следующая трактовка дискурса современного актуального искусства, под которым понимается «форма объективации содержания сознания, реализуемая художественными (изобразительными) средствами (языком искусства) в русле постмодернистской социально-культурологической концепции, расширяющей рамки искусства и размывающей границы между художественной и внехудожественной деятельностью, между искусством и жизнью» [1, с. 15].

Отметим, что специфика арт-дискурса заключается во вторичности его природы, так как он содержит в себе потребность как в творчестве, так и в коммуникации. Ввиду данной потребности функциями арт-дискурса являются интерпретация и комментирование. Такое функционирование происходит при анализировании объектов искусства посредством ментальных процессов вкупе с коммуникативными целями автора и () В. В. Рингевич, 2017. 
экстралингвистическими факторами. Можно утверждать, что артдискурс отражает современные явления с помощью языковых средств и представляет собой достаточно многогранное понятие. Прежде всего, это связный текст, интерпретирующий объект искусства в совокупности с экстралингвистическими факторами. Кроме того, артдискурс является коммуникативной деятельностью, где должен присутствовать отправитель и получатель информации. Важной частью данного вида дискурса является интерпретация получателем информации, согласно картине мира реципиента.

Как уже говорилось выше, одной из разновидностей артдискурса является литературный дискурс (во многих классификациях в этом значении используется термин «художественный дискурс»), под которым У. Эко понимает «коммуникативный процесс передачи информации от автора читателю, в результате чего рождается некоторое сообщение» [9, с. 47]. В. Карасик рассматривает художественный дискурс не как процесс или пространство, а как «текст, погруженный в ситуацию общения», допускающий «множество измерений» и взаимодополняющих подходов в изучении (прагмалингвистический, лингвокультурный, социолингвистический, психолингвистический, структурно-лингвистический) [3, с. 5-6].

К характеристикам и чертам литературного дискурса В. Степанова относит:

1) письменную форму;

2) целостность и завершенность, обозначенные рамками дискурсных фрагментов в рассматриваемых произведениях;

3) полиморфность: литературный дискурс может включать в себя практически любые виды дискурса;

4) стертые грани между категориями правды и лжи относительно объективной реальности [8, с. 22].

Основные функции литературного дискурса:

1) информативная: рассказать читателю о каких-либо событиях, оказать воздействие на его внутренний мир.

2) креативная: смоделировать «художественную реальность», способствующую созданию необходимого контекста для восприятия читателем определенных высказываний, для вызова ассоциаций.

Исходя из представленных выше определений, под литературным дискурсом будем понимать стратегический процесс 
порождения художественного текста и, как результат, сам художественный текст со всей его многомерностью, которая саморазвертывается в процессе взаимодействия текста и читателя.

Еще одной разновиднотью арт-дискурса является кинодискурс, который, по мнению А. Зарецкой, понимается как «связный текст, являющийся вербальным компонентом фильма, в совокупности с невербальными компонентами - аудиовизуальным рядом этого фильма и другими значимыми для смысловой завершенности фильма экстралингвистическими факторами, т. е. креолизованное образование, обладающее свойствами целостности, связности, информативности, коммуникативно-прагматической направленности, медийности и созданное коллективно дифференцированным автором для просмотра реципиентом сообщения (кинозрителем)» [2, с. 32]. Более широкое понимание кинодискурса представлено в работах С. Назмутдиновой, где он рассматривается как «семиотически осложненный динамичный процесс взаимодействия автора и кинореципиента, протекающий в межъязыковом и межкультурном пространстве с помощью средств киноязыка, обладающего свойствами синтаксичности, вербальновизуальной сцепленности элементов, интертекстуальности, множественности адресанта, контекстуальности значения, иконической точности, синтетичности» [7, с. 7].

Кинодискурс основывается на сценарии и создается с помощью инструментов киноязыка, к которым Ю. Лотман относит кадр, монтаж, музыкальное сопровождение, шумовые эффекты, крупный, далекий и панорамный планы, темп, мимику и жесты, речь персонажей и / или диктора и др. [4, с. 14]. Это говорит о том, что кинодискурс как таковой является квинтэссенцией оригинала произведения (в случае с экранизацией) и сценария, написанного по нему. На основе данного заключения выделим основные черты кинодискурса:

1) целостность и завершенность, обозначенные рамками оригинала произведения (в случае с экранизацией) и сценария, написанного по нему;

2) использование инструментов киноязыка, так как кинодискурсу присуща передача информации посредством вербальных и невербальных знаков и аудиовизуальная форма восприятия [4, с. 29-37];

3) синтез речевой деятельности личности с невербальным компонентом;

() В. В. Рингевич, 2017. 
4) наличие широких экстралингвистических факторов (культурно-идеологическая среда, в которой происходит коммуникация).

К функциям кинодискурса относятся:

1) информативная - передать информацию посредством вербальных и невербальных знаков, сообщить кинореципиенту о героях, каких-либо событиях;

2) функция воздействия - оказать влияние на внутренний мир реципиента.

Таким образом, в узком смысле под кинодискурсом будем понимать «устное, письменное, визуальное сообщение, выраженное вербальными / визуальными знаками». В более широком смысле кинодискурс - процесс создания, воспроизведения и восприятия фильма, включающий в себя синтез участников дискурса, а именно их речь, время и пространство их взаимодействия, с помощью которого происходит развертывание сюжета, построение образов героев и их взаимоотношений, а также раскрытие их характеров. Ввиду того, что артдискурс отражает современные явления с помощью языковых средств и представляет собой как связный текст, интерпретирующий объект искусства в совокупности с экстралингвистическими факторами, так и коммуникативную деятельность, где должен присутствовать отправитель и получатель информации, считаем правомерным утверждать, что литературный дискурс и кинодискурс являются видами арт-дискурса.

\section{Литература}

1. Андрианов М. С. Невербальная коммуникация : психология и право М. С. Андрианов. - М. : Ин-тут общегуман. исслед., 2007. - 256 с.

2. Зарецкая А. Н. Особенности реализации подтекста в кинодискурсе : автореф. дис. ... канд. филол. наук / А. Н. Зарецкая. - Челябинск, 2010. -22 с.

3. Карасик В. И. Языковый круг : личность, концепты, дискурс / В. И. Карасик. [2-е изд.]. - М. : Гнозис, 2004. -390 с.

4. Лотман Ю. М. Семиотика кино и проблемы киноэстетики / Ю.М.Лотман. Таллин : Ээсти Раамат, 1973. - $140 \mathrm{c}$.

5. Макаров М. Л. Основы теории дискурса / М. Л. Макаров. - М. : Гнозис, 2003. -159 с.

6. Манаенко Г. Н. Когнитивные основания информационно дискурсивного подхода к анализу языковых выражений и текста / Г. Н. Манаенко // Язык. Текст. Дискурс. Ставрополь, 2005. - Вып. 3 : Личность. Информация. Дискурс. - С. 22-32.

7. Назмутдинова С. С. Гармония как переводческая категория (на материале русского, английского, французского кинодискурса) : автореф. дис. ... канд. филол. наук / С. С. Назмутдинова. - Тюмень, 2008. - 21 с. 
8. Степанова В. В. Субъектная организация художественного текста и анализ его лексической структуры / В. В. Степанова // Русистика : лингвистическая парадигма конца ХХ века. - СПб., 1998. - 101 с.

9. Эко У. Отсутствующая структура : введение в семиологию / У. Эко. - СПб. : Симпозиум, 2006. - 548 с.

10. What is meant by "discourse analysis" [Electronic resource] / ed. S. Slembrouck ; University of Gent. - 2003. - Mode of access : http://www.umsl.edu/ wilmarthp/mrpc-webresources/discourse-analysis.html.

Стаття надійшла до редакиії 07.10.2017 p. 